\title{
Self-directed Learning in Music Teacher Education: Perspectives from Pre-service Music Teachers in South Korea
}

\author{
Jihae Shin \\ Ewha Womans Univeristy \\ \#363 Education building B room, 52, Ewhayeodae-gil, Seodaemun-gu, Seoul, 03760 Republic of Korea \\ e-mail: jhshin99@ewha.ac.kr \\ *Corresponding author: jhshin99@ewha.ac.kr
}

Published: 2 September 2020

Cite this article (APA): Shin, J. (2020). Self-directed learning in music teacher education: Perspectives from pre-service music teachers in South Korea. Malaysian Journal of Music, 9, 29-41. https://doi.org/10.37134/mjm.vol9.3.2020

\begin{abstract}
This aim of this study is to investigate the perspectives of Korean pre-service music teachers on self-directed thesis seminar conducted in the graduate teacher education program. This research focused on 1) the attitude of pre-service music teachers towards self-directed thesis seminar and 2) the impact of self-directed thesis seminar on the progress of the pre-service music teachers' performance. Ten pre-service music teachers participated in the researcher's thesis seminar. The results demonstrated that most of the participants were anxious and insecure in managing the various educational resources as well as monitoring the progress of their study. However, the selfdirected thesis seminar has indirectly provided the participants with a new learning environment to manage their own goals, initiate their own learning, and responsible for their own progress and outcomes. The findings also showed that collaborative learning is essential as an instructional approach in self-directed learning to enable the participants to share their views from different perspectives and develop critical thinking.
\end{abstract}

Keywords: action research, learner-centred, music teacher education, self-directed learning, teacher education

\section{Introduction}

Educators have considered self-directed learning (SDL) as an important platform for teacher education and professional development (Slavit \& McDuffie, 2013; Tillema, 2000). The definition of SDL is as follows:

Learning in which the conceptualisation, design, conduct and evaluation of a learning project are directed by the learner. This does not mean that self-directed learning is highly individualised learning which is always conducted in isolation. Learners can work in self-directed ways while engaged in group-learning settings. (Brookfield, 2009, p. 2615)

According to Zepeda (2013), the understanding of teaching practices develops when the teachers are directly involved in their learning processes and mooted by their personal interest. Generally, teachers preferred to initiate their own professional learning activities (Louws et al., 2017) and enjoyed considerable autonomy in directing their own capacity in learning (Garrison, 1997; Knowles et al., 2015). Therefore, SDL is an important concept in the study and practice of teacher education.

John Dewey was one of the first scholars who emphasised the concept of SDL (Williams, 2004). He explained that teachers should be able to control their own learning process (Dewey, 1938). Similarly, Knowles (1975) highlighted that adult learning needed to include learners' active 
involvement and the collaboration between professors and students. When defining SDL, many scholars tended to overemphasise the external management of SDL (Garrison, 1997). As a result, learners' independence in deciding what to learn and how to achieve their learning goals was only considered in promoting SDL environments, which caused the restriction of SDL implementation in an educational setting (Candy, 1991). In this regard, Garrison (1997) suggested that the concept of SDL should include elements of the cognitive and motivational dimensions of learning as well as the external management of SDL. Therefore, it is necessary to investigate the learning process of SDL through learners' contextual control, internal monitoring, and motivation to enter a task.

Within this context, this study is expected to investigate the learning process of pre-service music teachers who were involved in SDL environment where external management, internal monitoring, and motivational dimensions were incorporated.

\section{Background of Research}

I have been working as a teacher educator at a university in Seoul, South Korea for seven years. Improving on the teacher education programme in music was my primarily concern as an educator and a researcher. I have always aspired to empower my students to work independently on their thesis seminar project. After much consideration, I decided to shift from traditional teaching practice to student-centred learning. In this research, I introduced SDL in the graduate programme for pre-service music teachers. This new approach to learning enabled the pre-service music teachers to reflect and analyse on their own learning outcomes consistently (Simms, 2013).

This graduate programme required pre-service music teachers to complete 30 credits hours for a successful completion. The students have to enrol in a thesis seminar after completing their comprehensive examinations. Every student has an advisor to guide them in writing their thesis at end of the third semester. They have to complete the writing of their Master's thesis (60-150 double-spaced pages in length) and present their thesis in the fifth semester.

\section{Problem Statement}

Kim (2016) acknowledged that Asian students were generally quiet, passive, and they were more accustomed to teacher-centred learning. This submissive attitude may be influenced by the teachings of Confucius. Recently, the Korean government has introduced student-centred learning via SDL in schools to promote creativity and individuality. However, majority of the students in Korea still favoured teacher-centred learning and struggled to acclimatise to the new learning environment (Lee \& Park, 2014).

The writing of Master's thesis in the graduate program is an individual project, which required the pre-service music teachers to work independently on the project. However, most of the graduate students in my thesis seminar were not confident in managing their own research project. They faced difficulty in assessing their own learning progress, and determining the field of their study. They relied immensely on their advisors to help them solve their learning issues and advancement of their thesis. As a result, independent learning hardly occurred in the thesis seminar.

The need to develop independent learners in a thesis seminar is pertinent to enable the preservice music teachers to embrace new knowledge and improve on their teaching practice. Therefore, the purpose of this study is to investigate the perspectives of Korean pre-service music teachers on selfdirected thesis seminar, which they participated in their graduate program.

The research questions are as follows: 1) What is the attitude of pre-service music teachers towards self-directed thesis seminar? and 2) What is the impact of self-directed thesis seminar on preservice music teachers' performance? 


\section{Literature Review}

\section{Self-Directed Learning (SDL)}

Self-directed learning (SDL) is a process where learners are responsible in 1) identifying their own needs and objectives, 2) finding appropriate materials, 3) implementing learning strategies, and 4) evaluating outcomes (Knowles, 1975; Loyens et al., 2008). There are three dimensions in SDL: selfmanagement, self-monitoring, and motivation (Garrison, 1997). Firstly, learners are engaged in selfmanagement. They administer their own learning goals, devise their own learning methods, and determine their own learning resources. They are responsible in monitoring their own progress and outcomes, as well as finding new strategies in improving their learning concerns. The success of selfmanagement and self-monitoring in SDL depend on the individual's motivation which includes the readiness to commence and adhere to the task until it is completed.

The aspects required in designing SDL environment for teacher education encompassed individual learners' personal attributes, teaching efficacy, knowledge level, past experiences, motivation, course content, and relevant skills in studying (Beitler, 1998; Greveson \& Spencer, 2005). The external factors such as adequate resources and compelling vision of instruction in education programs play a vital role in regulating the learners' task motivation (Bullock, 2013; Slavit \& McDuffie, 2013). Also, authentic learning environments where learners have opportunities to construct knowledge and find solutions of real-life problems help them develop efficacy and self-directed learning skills (Hursen, 2016; Loyens et al., 2008). A gradual paradigm shift from teacher-centred approach to self-directed learning is integral to facilitate SDL among teachers (Bull, 2017; Levett-Jones, 2005; Williams, 2004).

There are several strategies to promote SDL. Collaborative learning among peers, teachers and experienced learners played a distinctive role in determining the success on SDL. The learners attained assistance, guidance and assessment from their collaborative partners in the SDL environment (Jin, 2015; Loyens et al., 2008; Silen \& Uhlin, 2008). According to Garrison (1997), collaborative learning allowed an individual to work independently on a task besides gaining constructive comments from their collaborators. The process of collaboration helped the learners to evaluate the progress of their study (Silen \& Uhlin, 2008) as well as to develop professional practice (Shin, 2018; Trust \& Horrocks, 2017). The use of appropriate tools and resources aided by technology as well as virtual support are also evident in the SDL environment (Bullock, 2013; Haidari et al., 2019). These technologies driven tools enabled the students to design fun, easy and quick learning activities (Haidari et al., 2019) besides enhancing collective learning (Rana et al., 2016).

Researchers in education often argued that the SDL environment affects the learning practice of the individual. Teachers are responsible for their own learning process and outcomes in SDL (Bullock, 2013; Seo, 2010). A positive SDL learning environment enhanced the teachers' teaching practice (Haidari et al., 2019; Slavit \& McDuffie, 2013; Tillema, 2000; van Garderen et al., 2017; van Wyk, 2017). Teachers who have successfully achieved fruition in their teaching practice through SDL will eventually impart the similar approach to their students (Lai et al., 2013).

There are many studies pertaining to self-directed learning for teachers. The research primarily focused on digital technology teacher (Bullock, 2013), preschool teacher (Seo, 2010), mathematics teacher (Slavit \& McDuffie, 2013), primary school teacher (Tillema, 2000), economics teacher (van Wyk, 2017), English teacher (Haidari et al., 2019) and special education teacher (Van Garderen et al., 2017).

However, there are very limited resources related to music teacher education program on SDL. The knowledge on SDL is instrumental for pre-service music teachers who played a principal role in developing the education system. These teachers tend to feel difficulty in monitoring their own thinking and seeking for improvement (Parsons \& Stephenson, 2005), so they need to experience SDL in teacher education programs in order to develop responsibility and accountability in teaching practice. There is also a need for pre-service teachers to experience SDL as a continuous professional development (CPD) in the teacher education program. CPD is essential in developing the teachers' responsibility and accountability in their teaching practice. Therefore, it is pertinent to examine the perspectives of pre-service music teachers on SDL during their participation in the graduate education program. 


\section{Method}

I used the action research methodology to investigate pre-service music teachers' experience in a selfdirected thesis seminar. Harris (2000) said:

In many aspects, this is an extension of a teacher's professionalism, where reflection and development of one's practice is crucial. Action research, though, takes this further by combining theory and practice in a powerful way. It is practical, based on one's own needs, and designed to improve one's practice. (p. 65)

The process of action research consists of nine steps (Mertler, 2016). The first step in action research is to identity and limit the topic. In this step, I reflected on my teaching experience and identified that SDL environments are necessary for music teacher education in Korea. Step 2 indicates gathering information, so I discussed the importance of SDL to pre-service music teachers with other professors, which confirmed that the research topic is necessary. The third step means reviewing the related literature, so I reviewed the information and knowledge closely related to SDL in books, research journals, and website. This related literature provided guidance for developing research design. In the fourth step, I developed a research plan. After defining research questions, I designed self-directed thesis seminar and recruited the participants in the study.

Step 5 indicates implementing the plan and collecting data. In this step, two groups participated in self-directed thesis seminar, and I collected participants' perspectives on this seminar using data from participants' reflective journals, researcher's reflective journal, and artefacts. In step 6, I analysed the data, and in step 7, I developed an action plan by proposing strategies for implementing SDL in music teacher education. Step 8 means sharing and communicating the results, so I wrote this research article to share the results with other colleagues in music education. In the final step, I reflected on the overall process of this action study.

\section{Self-Directed Thesis Seminar}

A self-directed thesis seminar is designed to ensure a better learning environment for the student teachers' culminating thesis project. This seminar enabled the pre-service music teachers to 1) seek their own research interests in education, 2) source their own resources and 3) execute their research in the fourth semester. This research methodology adapted the seven steps of self-directed professional learning outlined by Shurr et al. (2014), as shown in Figure 1. In self-directed thesis seminar, step 2 and 3 of self-directed professional learning are integrated into deciding individual research topics because both steps are closely related to making plans for identifying professional learning needs (Shurr et al., 2014). Also, step 5 and 6 are compressed into self-reflection because they frequently happen together. 


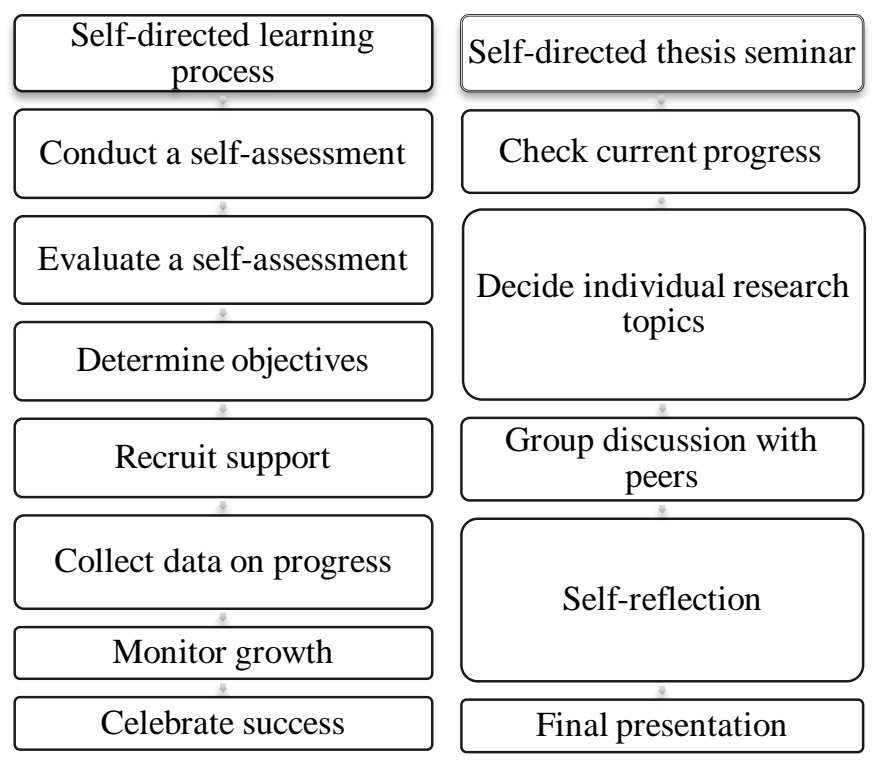

Figure 1. Seven steps of a self-directed thesis seminar.

In the first step, the learners conduct a self-assessment to evaluate their abilities and skills in a specific field (Shurr et al., 2014). My graduate students conducted a self-assessment on the progress of their research study. It is vital for them to reflect on the ideas and concepts of their research study. Before the inception of the seminar, the students were introduced to the basic research methods on music education in a course entitled 'Introduction to Research in Music Education'. We met on the first week of the seminar to recapitulate the topics learned. I tried to engage my students to assess their current progress and examine the needs to conduct their study.

In the second and third step, the students identify their learning needs (Shurr et al., 2014). My students identified the focus and objectives of their study based on their research interest. Upon completion, they presented their research topics and objectives to their peers, and received constructive criticism from them.

In the self-directed learning process, it is important to receive continuing support and comments from peers (Silen \& Uhlin, 2008). Finding trustworthy peers who can provide both constructive criticism and words of encouragement are essential in Step 4 (Shurr et al., 2014). In this recruitingsupport step, each participant presented what they studied about their research topics to their peers and received constructive comments from them. Collaborative approach enhanced one's learning process. Specific individual research topics are given to two groups as shown in Table 1.

Table 1

Individual seminar topic

\begin{tabular}{cccc}
\hline Schedule & Topics & Group 1 & Group 2 \\
& & (September to December, 2016) & (March to June, 2017) \\
\hline $1^{\text {st }}$ week & Orientation I & All participants & All participants \\
$2^{\text {nd }}$ week & Orientation II & All participants & All participants \\
$3^{\text {rd }}$ week & Quantitative study & Group seminar & Group seminar \\
& & (Donna's presentation) & (Mary's presentation) \\
& Individual work \\
$4^{\text {th }}$ week & Self-reflection & Individual work & Group seminar \\
$5^{\text {th }}$ week & Qualitative study & Group seminar & (Linda's presentation) \\
& & (Betty's presentation) & Individual work \\
$6^{\text {th }}$ week & Self-reflection & Individual work & Group seminar \\
$7^{\text {th }}$ week & Introduction & Group seminar & (Kim's presentation) \\
& & Individual work \\
\hline
\end{tabular}




\begin{tabular}{cccc}
\hline $9^{\text {th }}$ week & Research method & Group seminar & Group seminar \\
& (Laura's presentation) & (Susan's presentation) \\
$10^{\text {th }}$ week & Self-reflection & Individual work & Group seminar \\
$11^{\text {th }}$ week & Data analysis & Group seminar & (Helen's presentation) \\
& & (Jean's presentation) & Individual work \\
$12^{\text {th }}$ week & Self-reflection & Individual work & All participants \\
$13^{\text {th }}$ week & Final presentation & All participants & \\
\hline
\end{tabular}

In step 5 and 6, learners constantly check and monitor their progress to improve on their research plans in SDL (Shurr et al., 2014). Between the series of group seminars, my participants reflected on their thinking, knowledge, and understanding about their topics and identified a problem in learning. They also gathered befitting information and resources related to their own study to address the problems. Constant monitoring is needed to regulate the participants' academic progress and selfassessment on their learning strategies and resources used. The constant support, critical feedback, and stimulating challenges from the peers during group seminars enabled the participants to reflect and improve on their research progress.

In the final stage, step 7, the learners review the progress of their study and assess their utmost achievement (Shurr et al., 2014). All the participants in my thesis seminar presented their final projects and commended on each other's success in the last session of the seminar. Besides, they also reflected and discussed their experiences gained throughout the process of SDL.

\section{Participants}

The participants comprised two cohort groups of students who participated in my thesis seminar on the fourth semester of their program. I intentionally recruited two groups of students to gather rich data about pre-service music teachers' various attitudes and perspectives of their participation in SDL. The purposeful samplings (Tomal, 2010) is used to achieve the objectives of my study, which is to improve the participants' skills in conducting and administrating their own research study as well as teaching practice through SDL. The participants received notification on the purpose of the study and the research procedures through e-mails. All the ten, preservice teachers need to experience SDL in teacher preparation programs in order to develop responsibility and accountability students assigned to my seminar agreed to participate in my research study voluntarily. Donna, Betty, Ruth, Laura, and Jean (pseudonyms) participated in the first thesis seminar from September to December 2016; and Mary, Linda, Kim, Susan, and Helen (pseudonyms) joined the second thesis seminar from March to June 2017. These participants majored in music performance during their undergraduate schools; and they decided to enroll in the graduate program to become music teachers in the middle or high school.

\section{Data Collection}

For this study, I used multiple data collection methods such as participants' reflective journals, researcher's reflective journal, and artefact collection.

Participants' Reflective Journals. Journal writing is a tool used to assist pre-service teachers to reflect and assess their current practice (Goker, 2016). By putting their thoughts, feelings, expressions, and reflections into writing, these teachers are able to 1) examine the current progress in their study, 2) consider alternatives to solve their problems, and 3) source new knowledge and methods to improve on their study (Al-karasneh, 2014; Goker, 2016). In this study, participants are required to write regular reflective journal twice a month and send it to me via e-mail. Each participant wrote six to nine journal entries. I provided the pre-service music teachers with broad guidelines on how to write a reflective journal, which was adapted from previous research studies (Al-karasneh, 2014; Goker, 2016):

1. What main events happened today or this week? What were your decisions in terms of good learning practice?

2. What went well? What makes you think so? 
3. Record your thoughts and feelings during individual work and group seminars.

4. Describe and reflect your negative learning experience as well as positive experience.

5. What did you do to sustain the positive and avoid the negative?

Researcher's Reflective Journal. Besides collecting the participants' reflective journals, I also kept my own reflective journal. I recorded my observations, thoughts, and reflections on each participant in my journal. Documentation includes the progress of each individual participant as well as their learning process and accomplishment between theory and practice in the graduate program.

Artefact Collection. Artefacts enabled researchers to gain new insights on observations, journals, and interviews (LeCompte \& Preissle, 1993). In this study, I collected participants' research proposals, presentation handouts, and e-mails to examine the perspectives of their participation in this thesis seminar.

\section{Analysis}

Data analysis on the learning process of SDL among the pre-service music teachers in South Korea (Bernard \& Ryan, 2010) are conducted by using content analysis. At the initial stage, I read all the data collected to gain a holistic understanding of graduate students' experience in SDL. Then, I re-read the data to identify useful codes. The 10 codes established were joy, anxiety, confidence, peers, attitude, responsibility, critical thinking, collaboration, frustration, and improvement. Using constant comparative method, six clustered categories found encompassed joy in the learning process, frustration in SDL, responsibility, development of critical thinking, benefits from peers, and improvement in peer collaboration in SDL. Comparative study among the categories were done to identify the relationship between each group, and finally, five main themes were aggregated. The five themes include 1) attitude about SDL, 2) responsibility for learning process, 3) various perspectives from peers, 4) development of critical thinking, and 5) the way for effective collaboration in SDL. The main themes were refined according to the research questions 1) the attitude of pre-service teachers towards SDL and 2) the impact of self-directed thesis seminar on pre-service music teachers' performance. Data analysis comprised the similarities and differences among the participants.

Analysis on the coded data and its related texts were sent to the participants for verification (Tracy, 2010) to minimise errors and prejudice in analysing and interpreting the data as I am directly involved in the education program. To establish credibility in this study, I used peer examination to receive feedback on participant recruitment, methodology, data collections, research findings and interpretations (Merriam, 1998). Besides, peer debriefing allowed me to re-analyse emerging new categories and clarify the participants' attitudes towards SDL.

\section{Findings and Discussion}

The findings comprised two categories: (1) the graduate students' attitude on SDL and (2) the impact of SDL on graduate students' performance in their thesis seminar. Each category concluded with a discussion on SDL pertaining to pre-service music teachers.

\section{Attitude about SDL}

The findings demonstrated that most of the pre-service music teachers do not favour SDL at the beginning of the thesis seminar. They were apprehensive to conduct their studies in the new environment. The same stance also prevailed in my second observation. Refer to the researcher's reflective journal as stated below:

It is still difficult to implement SDL in the seminar... I have tried my best to gain the pre-service music teachers' confidence in working on their thesis by designing specific steps in SDL; but they were still apprehensive to learn in this new learning environment... What should I do? Do I need to revert to teacher-centred approach? What have I done wrong as their thesis advisor? 
They lacked confidence in choosing reliable and suitable learning resources from the various references. For example, Linda expressed her concerns in managing the materials and resources found in books, the internet, and databases:

It is difficult to find appropriate contents and materials for my study, especially when there is enormous information on the field of my study. Besides, I also faced difficulty in deciding the most relevant materials and information pertaining to my study.

Most of the participants lacked confidence in monitoring their own learning progress. In SDL, the participants were required to examine their progress and improve on their learning strategies constantly. However, most of the teachers were perplexed with their own ability in making decisions and assuring the correct learning outcomes. As reflected in Kim's journal below:

During the preparation of my work, I have to change my research variables constantly. At one moment, I decided to focus on music teachers' attitude towards music teaching and teaching anxiety. Nevertheless, I am not sure whether these variables are significant and related to the previous studies. Through my observation, I think there is a need to modify my research topic. Again, I am not sure whether I have made the correct decision.

The findings showed that only two out of ten participants enjoyed the journey of SDL. In her fourth journal, Susan, from the second group, mentioned that she enjoyed learning, found that the process interesting and discovered new learning strategies in improving herself:

I decided to focus on a specific research question, and it helped me in designing the questionnaire. I was able to complete the outline of the survey quite easily. While studying on the research methods, I found two useful references as a guide. I chose the participants in my study and designed the survey instrument based on the references. It was quite an interesting experience for me. Of course, I realised that I might need to modify and re-design my survey; however, the learning process itself was rewarding and enjoyable.

The initial stage of SDL proved a burden for all the participants. However, a few of them began to appreciate the process of SDL after experiencing progress in their study. As discovered by Donna in her journal:

At the beginning, it was difficult for me to read all the resources related to my study and it was a great pressure on me. However, as my study progressed, I began to enjoy the new learning environment. I really liked the learning process where I could study independently. That experience motivated me to participate in other learning activities more confidently and actively.

The findings contradicted from Lai et al. (2013), and showed that there were constant anxiety among most participants (except two) towards the process of SDL since its inception. As the thesis seminar progressed, I realised that most of the participants lacked experience and confidence in SDL. The complexity in their research project and thesis writing further doubted their confidence in participating in SDL.

After observing the graduate students for almost four months, I realised that they should have started SDL in topics familiar to them. The participants kept complaining that SDL was new to them. Explaining the purpose and the process of SDL at the beginning of the seminar was not sufficient to boost their confidence in this new environment. I should have designed a more detailed and specific plan to engage them in SDL.

As said in Bull (2017) and Levett-Jones (2005), an abrupt change from teacher-centred learning to SDL might trigger anxiety, fear, and criticism among the learners. It is more effective to implement SDL to the learners by introducing collaboration with a teacher to set up goals and assess learning progressively (Bull, 2017; Williams, 2004). Most of the music courses offered in the teacher education program at my school focused on teacher-centred approach. The pre-service music teachers were unacquainted to setting up their own goals, working independently and finding suitable learning 
materials. Besides, the challenges encountered in their research projects further restrained them from enjoying the fruition of SDL since its inception. Therefore, I suggest that the students should be motivated to SDL through familiar and easier topics offered in the program (Greveson \& Spencer, 2005). Progressive introduction of SDL is essential to enable them to understand its purpose and methods (Levett-Jones, 2005). SDL should be introduced successively to develop personal and cognitive skills as well as improving the process of learning.

Furthermore, it is significant that participants with positive attitude towards SDL also noticed the favourable outcomes from SDL. According to Lai et al. (2013) and Levett-Jones (2005), participants who have had achieved assuring outcomes from SDL are affirmative towards its learning environment. This finding suggests pre-service music teachers to discern their own progress in their study in SDL.

\section{The Impact of SDL on Graduate Students' Performance in a Thesis Seminar}

This study showed that self-directed thesis seminar helped graduate students become more responsible in their learning process, get various perspectives from peers, and develop their critical thinking.

Responsibility in Learning Process. All the participants agreed that they were responsible in setting and managing their own goals during the learning process. As expressed by Jean in her reflections on the SDL:

While I was in a graduate school, I had a lot of opportunities to work on various projects. I took on the tasks given by my professors without questioning the reasons to work on those assignments and projects. As for my research, I had the opportunity to decide on my own study. I decided to analyse quantitative and qualitative findings. It was a good experience for me to initiate my own learning experience. During this learning process, I became more responsible in making decisions pertaining to my own study.

The respondents opined that the experience in deciding their own goals enabled them to manage their own study more effectively and self-sustaining. Betty mentioned the responsibility in learning in her reflective journal:

While participating in the seminar, I realised that I need to improve on my knowledge in research. Therefore, I proceeded to study on research methods, data analysis and qualitative methods by myself. This experience differed from the teacher-centred learning. As a responsible learner, I worked very hard and it helped me to remember what I have learned.

As stated by Bullock (2013), Lai et al. (2013) and Seo (2010), this study also showed that preservice music teachers were responsible for their own learning process and outcomes in the SDL environment. In the SDL process, it is important to create a positive learning environment that encourage learners to engage in their own study confidently (Bullock, 2013; Slavit \& McDuffie, 2013). Thus, I put into consideration the pre-service music teachers' needs and interest when designing this self-directed thesis seminar (Beitler, 1998; Hursen, 2016; Slavit \& McDuffie, 2013). The teachers enjoyed learning new knowledge while managing their own goals and initiating their own learning experience. This finding supported the concept of SDL (Brookfield, 2009; Garrison, 1997). The preservice music teachers decided on their own learning during the self-management process; were responsible for establishing their own professional knowledge; and were motivated to continue to work hard.

Various Perspectives from Peers. The pre-service music teachers also valued the comments and feedback given by their peers from different perspectives in the seminar. At the beginning of the seminar, they were hesitant to participate actively in group discussions. However, they picked up the momentum in the second meeting.

In their reflective journals, these respondents commented on meaningful learning through active peer discussions. They acknowledged the positive feedback given by their peers to enhance their research topics and thinking process. As acknowledged by Betty the advantages of peer collaboration in her reflective journal: 
Today all of us read Ruth's research introduction and give her some suggestions. In fact, I have not written on my introduction yet, and it is quite difficult for me to comment. However, it is interesting to note that different suggestions and opinions were raised during peer discussion although we read the same thing. I think that was useful during peer collaboration.

Through peer discussions, the pre-service music teachers modified their research focus and find alternative resources to collect and analyse their data. For example, in Mary's reflective journal, she showed her appreciation on the various suggestions given by her peers in choosing samplings for her study:

"During my presentation, my peers asked me about the frequency of attendance during weekly woodwind band practice and the duration of practice. I couldn't answer those questions... Helen highlighted to me that the school's learning environment played an important role in determining the quality of the school band. I haven't thought of that, and I need to consider those issues before choosing my samples."

In the researcher's journal, I also noted that the collaboration in SDL enabled the pre-service music teachers to consider different perspectives to improve on their research topics:

It was very interesting to observe the conversations among the pre-service music teachers. Especially, Helen seemed to gain various ideas to analyse her qualitative data from others' perspectives... Today, I realise the importance of collaborative process in SDL. This process is very effective in helping them to be more self-directed learners.

All the pre-service music teachers in this study agreed that collaboration among peers was an integral factor in helping them to conduct their own research in the SDL process successfully. As said in Conway et al., (2010) and Shin (2018), the pre-service music teachers also enhanced their thoughts and developed their learning process based on the perspectives given their peers. These participants also managed to monitor and improve on their research methods as well as strategies.

Development of Critical Thinking. It is interesting to note that the participants managed to think and evaluate their own topics, resources, and progress more objectively and critically after reading their peer's assignment and participating actively in the discussion. As mentioned by Kim in her final reflective journal about her experience in the self-directed thesis seminar:

One of the most important advantages of this seminar was that I could look at my work objectively beyond bias. After reading others' work and considering others' perspectives, I could monitor the progress of my work more critically.

Echoing the same sentiment, Helen, in the second group, agreed that the opportunity to view and reflect on others' research work enabled her to monitor and improve the quality of her own research study:

I tried assessing my colleagues' work objectively and posted critical comments as well as quizzing questions to them. I tried to recall and reflect on those questions during my own study. I noticed that I could concentrate more on managing resources and organising my research plan through recalling the comments from peer group's discussion. For example, What if this works ... if I were to write it this way? I think collaborative learning is imperative to assist me in learning critically.

It is also inspiring to learn that the participants gained deeper understanding of their own work after participating actively in the peer group's discussion as well as reading their peer's assignments. Peer collaboration in SDL promotes objective perception of their research process. The pre-service music teachers gained deeper insights into their own learning process, which eventually led them to perform well in the self-directed thesis seminar.

Goodloe (2015) argued that "one way to demonstrate critical thinking is by examining one's own values through reflecting, questioning, writing, and analysing personal beliefs and the perspectives of others" (p. 47). Participants in this study showed that they learned to assess the quality of research 
work by reading objectively, reflecting and questioning others' assignments as well as their own. Throughout this process, these pre-service teachers were able to assess and improve the quality of their own work in SDL. During my observation, I realised that questioning others' work is pertinent in promoting critical thinking among the pre-service teachers' in SDL. This process enabled them to manage, monitor, and assess their learning progress more critically.

The Way for Effective Collaboration in SDL. All the participants consensually agreed to the advantages of the collaborative learning in SDL thesis seminar. They also gave their suggestions to improve peer collaboration in SDL. Donna commented that it was difficult for her to read her peers' work in a short period during the seminar:

I was not confident in giving feedback to Laura's assignment because I was not sure whether I have fully understood her work and intentions... Therefore, I hope that we could get the materials earlier so that we could have ample time to read and think about it before peer group discussion.

Laura further suggested that the participants post their work before peer group discussion through social network services such as Facebook and blogs to enable effective group discussion and collaboration:

I think Donna has worked very hard on her assignment, however we were not ready to comment in the seminar. It would be more effective if the participant post their work for us to read earlier through Facebook or blogs. I think this method saves time and enables us to participate more actively and confidently.

This study distinctively showed that the pre-service music teachers also valued virtual space besides face-to-face seminar meeting. Online meetings played an important role in facilitating music teachers' group discussions. Shin (2018) argued that both face-to-face meetings and online communications facilitated interactions among music teachers, and Trust and Horrocks (2017) confirmed that "blending informal and formal learning activities optimise the overall learning experiences" (p. 658). The pre-service music teachers also concurred that virtual meetings provide them with more time to read and evaluate their peers' work for group discussion. Therefore, it is necessary to encourage the participants to post and review their peers' work in the virtual platforms without restraining to time constraint.

\section{Conclusion and Recommendations}

SDL is primarily important to enable pre-service music teachers to pursue continuous professional development throughout their teaching careers (Zepeda, 2013). SDL in a teacher education program empowered pre-service music teachers in managing their own learning. The participants were responsible for their own learning process and outcomes besides enjoying the new learning environment. As suggested by Bullock (2013) and Slavit and McDuffie (2013), I encouraged preservice music teachers to decide on the field of their study based on their interest, initiate and manage their own goals and take responsibility in their own learning process.

However, the participants faced difficulty in engaging into the new learning environment. Most participants felt insecure in managing their learning resources and monitoring the progress of their learning. Hence, my suggestion is to incorporate the learning process in SDL progressively to enable participants to benefit from it. The course content should be familiar to the participants to enable them to develop positive attitude in designing, conducting, and assessing their learning confidently.

The findings also showed that collaborative learning is an effective instructional approach to elicit peers' comments and feedback from various perspectives besides developing critical thinking among the participants. The ability to read and question others' work indirectly helped the participants to reflect and review their own learning progress in SDL. The ability to focus and understand the context of others' research eventually helped the participants to self-monitor their own studies critically (Goodloe, 2015). Therefore, it is vital to encourage participants to review and comment their peers' task collaboratively in SDL to generate critical thinking and constructive self-monitoring. 
Furthermore, virtual spaces are also significant in engaging collaborative learning among the pre-service music teachers besides in-person meetings in SDL environment. The use of technology is prevalent among the pre-service music teachers in the teacher education program. Therefore, there is a need for music educators to consider incorporating technology in SDL to assist pre-service music teachers in managing and monitoring their learning successfully and independently.

\section{References}

Al-karasneh, S. M. (2014). Reflective journal writing as a tool to teach aspects of social studies. European Journal of Education, 49(3), 395-407. https://doi.org/10.1111/ejed.12084

Beitler, M. A. (1998). Mid-career adults in self-directed graduate programs. In H.B. Long \& Associates (Eds.), Developing paradigms for self-directed learning (pp.179-193). College of Education, University of Oklahoma.

Bernard, H. R., \& Ryan, G. W. (2010). Analyzing qualitative data: Systematic approaches. SAGE Publications.

Brookfield, S. D. (2009). Self-directed learning. In R. Maclean \& M. Wilson (Eds.), International handbook of education for the changing world of work (pp. 2615-2617). Springer.

Bull, B. D. (2017). Adventures in self-directed learning: A guide for nurturing learner agency and ownership. Wipf and Stock Publishers.

Bullock, S. M. (2013). Using digital technologies to support self-directed learning for pre-service teacher education. The Curriculum Journal, 24(1), 103-120. https://doi.org/10.1080/09585176.2012.744695

Candy, P. C. (1991). Self-direction for lifelong learning. Jossey-Bass.

Conway, C. M., Eros, J., Pellegrino, K., \& West, C. (2010). The role of graduate and undergraduate interactions in the development of pre-service music teachers and music teacher educators: A self-study in music teacher education. Bulletin of the Council for Research in Music Education, 183, 49-64.

Dewey, J. (1938). Experience and education. Collier Macmillan.

Garrison, D. R. (1997). Self-directed learning: Toward a comprehensive model. Adult Education Quarterly, 48(1), 18-33. https://doi.org/10.1177/074171369704800103

Goker, S. D. (2016). Use of reflective journals in development of teachers' leadership and teaching skills. Universal Journal of Educational Research, 4(12A), 63-70. https://doi.org/10.13189/ujer.2016.041309

Goodloe, J.-E. (2015). Promoting critical thinking and reflection in a capstone course for adult learners [Unpublished doctoral dissertation]. Walden University, Minneapolis.

Greveson, G. C., \& Spencer, J. A. (2005). Self-directed learning-the importance of concepts and contexts. Medical Education, 39(4), 348-349. https://doi.org/10.1111/j.1365-2929.2005.02115.x

Haidari, S. M., Yelken, T. Y., \& Akay, C. (2019). Technology-enhanced self-directed language learning behaviors of EFL student teachers. Contemporary Educational Technology, 10(3), 229-245. https://doi.org/10.30935/cet.590003

Harris, R. (2000). An action research project to improve the quality of A Level history writing. Prospero, 6(3\&4), 65-79.

Hursen, C. (2016). The impact of curriculum developed in line with authentic learning on the teacher candidates' success, attitude and self-directed learning skills. Asia Pacific Education Review, 17(1), 73 86. https://doi.org/10.1007/s12564-015-9409-2

Jin, D.-L. (2015). A study on the development and application of program utilizing e-portfolios for the improvement of self-directed learning within underachieving undergraduate students [Unpublished master's thesis]. Kyung Hee University, Seoul, Korea.

Kim, J. Y. (2016). Group work oral participation: Examining Korean students' adjustment process in a US university. Australian Journal of Adult Learning, 56(3), 400-423.

Knowles, M. S. (1975). Self-directed learning: A guide for learners and teachers. Association Press.

Knowles, M. S., Holton, E. F., \& Swanson, R. A. (2015). The adult learner: The definitive classic in adult education and human resource development (Vol. 8). Routledge.

Lai, C., Gardner, D., \& Law, E. (2013). New to facilitating self-directed learning: The changing perceptions of teachers. Innovation in Language Learning and Teaching, 7(3), 281-294. https://doi.org/10.1080/17501229.2013.836208

Levett-Jones, T. L. (2005). Self-directed learning: Implications and limitations for undergraduate nursing education. Nurse Education Today, 25, 363-368. https://doi.org/10.1016/j.nedt.2005.03.003

LeCompte, M. D., \& Preissle, J. (1993). Ethnography and qualitative design in educational research ( $2^{\text {nd }}$ ed.). Academic Press, INC.

Lee, J., \& Park, D. (2014). Do American and Korean education systems converge? Tracking school reform policies and outcomes in Korea and the USA. Asia Pacific Education Review, 15(3), 391-399. https://doi.org/10.1007/s12564-014-9325-x 
Louws, M. L., Meirink, J. A., Veen, K. V., \& Driel, J. H. V. (2017). Teachers' self-directed learning and teaching practice: What, how, and why teachers want to know. Teaching and Teacher Education, 66, 171-183. https://doi.org/10.1016/j.tate.2017.04.004

Loyens, S. M. M., Magda, J., \& Rikers, R. M. J. P. (2008). Self-directed learning in problem-based learning and its relationships with self-regulated learning. Educational Psychology Review, 20(4), 411-427. https://doi.org/10.1007/s10648-008-9082-7

Merriam, S. (1998). Qualitative research and case study applications in education. Jossey-Bass Publishers.

Mertler, C. A. (2016). Action research: Improving schools and empowering educators (5th ed.). SAGE Publications.

Parsons, M., \& Stephenson, M. (2005). Developing reflective practice in student teachers: Collaboration and critical partnerships. Teachers and Teaching: Theory and Practice, 11(1), 95-116. https://doi.org/10.1080/1354060042000337110

Rana, S., Ardichvili, A., \& Polesello, D. (2016). Promoting self-directed learning in a learning organization: Tools and practices. European Journal of Training and Development, 40(7), 470-489. https://doi.org/10.1108/EJTD-10-2015-0076

Seo, M. S. (2010). Strategic changes of preschool teachers' structuring of knowledge in self-directed learning. Journal of Early Childhood Education, 30(2), 357-380.

Shin, J. (2018). Using interactions among in-service music teachers in a graduate programme for teacher support. Music Education Research, 20(1), 114-125. https://doi.org/10.1080/14613808.2017.1301413

Shurr, J., Hirth, M., Jasper, A., McCollow, M., \& Heroux, J. (2014). Another tool in the belt: Self-directed professional learning for teachers of students with moderate and severe disabilities. Physical Disabilities: Education and Related Services, 33(1), 17-38. https://doi.org/10.14434/pders.v33i1.4855

Silen, C., \& Uhlin, L. (2008). Self-directed learning-a learning issue for students and faculty! Teaching in Higher Education, 13(4), 461-475. https://doi.org/10.1080/13562510802169756

Simms, M. (2013). A teacher-educator uses action research to develop culturally conscious curriculum planners. Democracy \& Education, 21(2), 1-10.

Slavit, D., \& McDuffie, A. R. (2013). Self-directed teacher learning in collaborative contexts. School Science and Mathematics, 113(2), 94-105. https://doi.org/10.1111/ssm.12001

Tillema, H. H. (2000). Belief change towards self-directed learning in student teachers: immersion in practice or reflection on action. Teaching and Teacher Education, 16(5-6), 575-59. https://doi.org/10.1016/S0742051X(00)00016-0

Tomal, D. R. (2010). Action research for educators ( $2^{\text {nd }}$ ed.). Rowman \& Littlefield Publishers.

Tracy, S. J. (2010). Qualitative quality: Eight "Big-Tent" criteria for excellent qualitative research. Qualitative Inquiry, 16, 837-851. https://doi.org/10.1177/1077800410383121

Trust, T., \& Horrocks, B. (2017). 'I never feel alone in my classroom': Teacher professional growth within a blended community of practice. Professional Development in Education, 43(4), 645-665. https://doi.org/10.1080/19415257.2016.1233507

Van Garderen, D., Hanuscin, D., Thomas, C. N., Stormont, M., \& Lee, E. J. (2016). Self-directed learning to improve science content knowledge for teachers. Intervention in School \& Clinic, 52(4), 236-242. https://doi.org/10.1177/1053451216659476

Van Wyk, M. M. (2017). An e-portfolio as empowering tool to enhance students' self-directed learning in a teacher education course: A case of a South African university. South African Journal of Higher Education, 31(3), 274-291. https://doi.org/10.20853/31-3-834

Williams, B. (2004). Self-direction in a problem based learning programme. Nurse Education Today, 24(4), 277-285. https://doi.org/10.1016/j.nedt.2004.01.008

Zepeda, S. J. (2013). Professional development: What works (2nd ed.). Routledge.

\section{Biography}

Jihae Shin is an assistant professor in a graduate school of education at Ewha Womans University, Seoul, South Korea, where she teaches music education courses. She earned her master's degree at the Ohio State University and doctoral degree at Teachers College, Columbia University, USA. Her research interests focus on teacher education, professional development, string music education, and music teaching and learning. 